\title{
Pendidikan Agama Kristen dalam Keluarga di Era Digital
}

\author{
Sri Wahyuni \\ Sekolah Tinggi Teologi Lintas Budaya Batam \\ sriwa.20@gmail.com
}

\begin{abstract}
This article talks about Christian education in the family in digital era. Its purposes are to increase the quality of Christian education for children, their faithfulness and morality. As we know that education in digital era has brought both positive and negative impacts, thus a wise thinking and proper actions are needed to overcome any issues that may arise in the emerging world. Undeniable that parents are also participating in the growth and development of their children's education since family is the center and foundation to build their character. This article study is written using qualitative research method along with literature research.
\end{abstract}

Keywords: Christian family; Christian education; digital era

\begin{abstract}
Abstrak: Artikel ini membahas tentang Pendidikan Agama Kristen Dalam Keluarga di Era Digital dengan tujuan untuk meningkatkan mutu pendidikan anak, beriman serta bermoral. Pendidikan di Era Digital memiliki sisi positif maupun negatif, namun bagaimana bisa menyikapinya secara bijaksana ditengah-tengah dunia yang makin maju dan berkembang. Pertumbuhan dan perkembangan pendidikan anak tidak terlepas dari peran orang tua. Orang tua mengambil andil didalamnya. Pendidikan dimulai di keluarga sebab keluarga adalah pusat dalam pembentukan karakter. Artikel ini menggunakan metodologi penelitian kualitatif dengan kajian literatur.
\end{abstract}

Kata Kunci: era digital; keluarga Kristen; pendidikan agama Kristen

\section{PENDAHULUAN}

Era Digital ditandai dengan munculnya serta memuncaknya perkembangan Ilmu Pengetahuan dan Teknologi (IPTEK) sehingga berdampak besar terhadap peran keluarga sebagai pusat yang utama dalam mendidik anak. Di tengah situasi yang semakin sulit peran orang tua sebagai wakil Allah maka semakin diperlukan untuk menunjukkan kasih, keadilan dan kehendak-Nya kepada anak-anak. Dampak positif atas kemajuan teknologi mestinya semakin kita mengasihi dan mencintai Tuhan dan sesama, makin berkembangnya pengetahuan dan pengalaman-pengalaman yang didapatkan, sehingga kita terus berkontribusi dalam bidang pendidikan Kristen. Dampak negative atas kemajuan teknologi harus diimbangi dengan kepedulian yang besar untuk mengajar anak menurut Alkitab, sehingga sekalipun anak hidup di dunia modern yang penuh dengan kemerosotan spiritual, karakter, moralitas, anak-anak Allah tetap menunjukkan kualitas hidup/imannya yang berbeda. Sehingga dengan demikian anak-anak Allah mampu menjadi berkat bagi banyak orang. 
Dalam bukunya yang berjudul Aristek Jiwa, Stephen Tong menyatakan bahwa: pendidikan keluarga mempunyai keuntungan yakni: waktu yang paling banyak, pengaruh yang paling besar, menguasai periode yang paling utama, memiliki pengenalan sifat pembawaan yang paling mendalam dan kemungkinan monitor yang

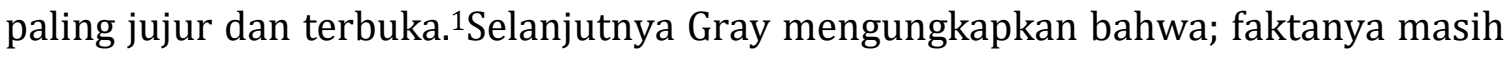
banyak orang tua menganggap bahwa pendidikan agama yang diperoleh anak di Sekolah Minggu serta lembaga pendidikan formal sudah cukup. Sehingga sebagaian lainnya terjebak dalam pola pendidikan permisif dengan pola pemikiran humanistik. John Gray mewakili pandangant ersebut yaitu semua anak dilahirkan baik dan tak berdosa. ${ }^{2}$

Dengan demikian pendidikan seharusnya dimulai dikeluarga, sebab keluarga adalah pusat dalam pembentukan karakter, serta ilmu pengetahuan yang langsung diterima oleh anak. Namun sebagai orang tua mereka mengabaikan tanggung jawabnya dalam mendidik dan membesarkan anak. Karena mereka menganggap bahwa karakter dan pendidikan itut erjadi di sekolah dan itu sudah cukup. Fenomena lainnya yang terjadi adalah meningkatnya kekerasan terhadap anak yang dilakukan oleh orang tuanya sendiri. Orang tua tidak lagi menjalankan fungsinya sebagaimana mestinya. Padahal keluarga/orang tua adalah tempat yang paling aman dalam memberikan kasih sayang, perhatian, perlindungan, pengakuan, penerimaan, tempat yang paling baik dalam pertumbuhan karakter dan kerohanian anak. Namun justru yang terjadi ialah keluarga tidak lagi tempat yang memberikan kasih sayang, tidak ada perhatian, tidak ada pengakuan, dan penerimaan yang baik. Justru orang tua/keluarga menjadi pelaku kekerasaan terhadap anak-anaknya sendiri. Peranan ayah dan ibu menjadi dingin dan ini ancaman yang mengerikan di rumah.

Ada beberapa pertanyaan; apa dan mengapa pendidikan Kristen begitu penting dalam keluarga di era digital? Bagaimana presfektif iman Kristen tentang pendidikan dalam keluarga? Tulisan ini akan membahas pentingnya pendidikan dalam keluarga di era digital, bagaimana presfektif iman Kristen terkait dengan pendidikan terhadap anak. Dengan demikian penulis akan memaparkan bagian-bagian ini pada penjelasan selanjutnya.

\section{METODE PENELITIAN}

Menurut Kholifah dan Suyadnya dalam bukunya menyatakan bahwa penelitian kualitatif berupaya mengungkapkan fenomena besar (bigpotraits) tersebut melalui kedalaman pengetahuan atas fenomena. ${ }^{3}$ Bogdan dan Taylor (1975:5) mendefinisikan metodologi kualitatif sebagai prosedur penelitian yang meng-hasilkan data deskriptif berupa kata-kata tertulis atau lisan dari orang-orang dan perilaku yang

${ }^{1}$ Stephen Tong, "Arsitek Jiwa 1"( Jakarta: Lembaga Reformed Injili Indonesia, 2009), 60.

2 John Gray, "Children Are From Heaven: Cara Membesarkan Anak SecaraPositif Agar Anak MenjadiKooperatifPercayaDiri Dan MemahamiPerasaan Orang lain"( Jakarta: PT Gramedia Pustaka, 2004),1.

${ }^{3}$ Siti Kholifah\& I WayanSuyadnya, "Metodologi Penelitian Kualitatif Berbagai Pengalaman Dari Lapangan" (Depok: PT Raja GrafindoPersada, 2018), 11 
dapat diamati. Menurut mereka pendekatan ini diarahkan pada latar dan individu tersebut secara holistic (utuh) jadi, dalam hal ini tidak boleh mengisolasikan individua tau organisasi kedalam variable atau hipotesis, tetapi perlu memandangnya sebagai bagian dari sesuatu keutuhan. Denzin dan Lincoln 1987), menyatakan bahwa penelitian kualitatif adalah penelitian yang menggunakan latar alamiah, dengan maksud menafsirkan fenomena yang terjadi dan dilakukan dengan jalan melibatkan berbagai metode yang ada. Dengan penelitian yang memanfaatkan wawancara terbuka untuk menelaah dan memahami sikap, pandangan, perasaan, dan perilaku individua tau sekelompok orang.

Sementara penulisan lain memaparkan bahwa penelitian kualitatif penelitian yang menggunakan pendekatan naturalistik untuk mencari dan menemukan pengertian atau pemahaman tentang fenomena dalam suatu latar yang berkonteks khusus. ${ }^{4}$ Senada dengan Juliansyah mengungkapkan bahwa penelitian kualitatif dilakukan pada kondisi yang alamiah dan bersifat penemuan. Dalam penelitian kualitatif, peneliti merupakan instrument kunci. Peneliti harus memiliki bekal teori dan wawasan yang luas jadi bias bertanya, menganalisis, dan mengkonstruksi objek yang diteliti menjadi lebih jelas. ${ }^{5}$ Maka artikel ini mengunakan metode penelitian kualitatif dengan memakai kajian perpustakaan yakni memakai berbagai sumber sumber ilmu pengetahuan yang masih relevan.

\section{PEMBAHASAN}

\section{Pentingnya Pendidikan dalam Keluarga pada Masa Anak}

Perkembangan yang terjadi pada manusia adalah perkembangan yang alamiah yakni mulai dari pembuahan sampai meninggal dunia. Pada bagian ini penulis akan membahas mengenai pendidikan keluarga pada masa anak. Masa anak-anak adalah masa yang paling indah dan penting dalam kehidupan setiap orang. Dimana pada masa ini mengalami proses pertumbuhan dan perkembangan secara cepat, baik fisik maupun psikologisnya. Sri Wahyuni dalam bukunya mengungkapkan; semenjak ilmu pengetahuan dan teknologi telah berkembang pesatnya, terutama gadet (era digital) dan pendidikan, maka fase-fase perkembangan manusia telah diperinci dan ciri-ciri serta gejala-gejala yang tampak pada setiap fase perkembangan itu dipelajari secara mendalam. Di dalam fas-fase perkembangan itu, masa anak-anak atau pun masa remaja merupakan pusat perhatian. Hal ini disebabkan karena merupakan masa transisi dari masa anak-anak ke masa remaja. Perubahan yang terjadi termasuk drastis pada hampir semua aspek perkembangan yaitu meliputi perkembangan fisik, kognitif, kepribadian, dan sosial. ${ }^{6}$

Hanya satu ilmu yang membahas tentang kehidupan manusia "di seberang sana", yaitu alam dunia orang mati menuju surga yang kekal, yaitu pendidikan agama. Di dalam agama, seseorang belajar tentang bagaimana seharusnya menjalankan

\footnotetext{
${ }^{4}$ Lexy J. Moleong, "Metodologi Penelitian Kualitatif Edisi Revisi” (Bandung: PT RemajaRosdakarya, 2010), 4-5

5Juliansyah Noor," MetodologiPenelitian", (Jakarta: KencanaPrenada Media Group, 2011), 34

${ }^{6}$ Sri Wahyuni , "Psikologi Remaja: Penanggulangan Kenakalan Remaja"(Luwuk Banggai: Pustaka Star's Lub, 2021), 49
} 
kehidupan di dunia ini agar sesuai ajaran yang di firmankan-Nya, sekaligus mempersiapkan diri menyongsong kehidupan yang akan datang. Tidak ada ilmu pengetahuan apapun yang membahas aspeki ini, selain agama karena kehidupan di seberang sana, diluar perhatian dan wewenang ilmu pengetahuan. Oleh karena itu pendidikan agama sangat penting diperhatikan oleh setiap orang karena selain memiliki dimensi horizontal, yakni menyangkut relasi antar sesama, agama juga memiliki dimensi vertical, yakni menyangkut relasi dengan Sang Khalik. ${ }^{7}$

Senada dengan Agoes Soejanto dalam bukunya mengungkapkan; setiap anak mengalami proses pertumbuhan dan perkembangan melalui tahap yakni:

1. Sejak lahir sampai 5 tahun.

2. Masa anak dari umur 6-12 tahun.

3. Masa pubertas dari umur 13-22 tahun.

4. Masa adolesen sebagai masa tansisike masa dewasa. ${ }^{8}$

Selanjutnya Elizabeth B. Hurlock, menulis jika dibagi berdasarkan bentuk-bentuk perkembangan dan pola-pola perilaku nampak khas bagi usia-usia tertentu, maka rentangan kehidupan terdiri atas sebelas masa, yaitu:

1. Prenatal: saat konsepsi sampai akhir.

2. Masa neonates: lahir sampai akhir minggu ke dua setelah lahir.

3. Masa bayi: akhir minggu kedua sampai akhir tahun kedua.

4. Masa kanak-kanak awal: dua tahun sampai enam tahun.

5. Masa kanak-kanak akhir: enam tahun sampai sepuluh tahun.

6. Pubertas/preadolescence: sepuluh tahun atau dua belas tahun sampai tiga belas tahun.

7. Masa remaja awal: tiga belas tahun atau empat belas tahun sampai tujuh belas tahun.

8. Masa remaja akhir: tujuh belas tahun sampai dua puluh satu tahun.

9. Masa dewasa awal: dua puluh satu tahun sampai empat puluh tahun.

10. Masa setengah baya: empat puluh tahun sampai enam puluh tahun.

11. Masa tua: enam puluh tahun sampai meninggal dunia. ${ }^{9}$

Dengan demikian, bertambahnya umur maka anak-anak akan memperhatikan kemajuannya untuk mencapai sesuatu melalui apa yang dilihatnya. Maka belajar merupakan suatu cara untuk memperoleh pengetahuan melalui pendidikan dan ilmu teknologi di era digital serta melalui pengalaman-pengalaman yang didapatkannya. Maka belajar adalah merupakan perubahan seumur hidup yang terjadi sebagai akibat/hasil yang diperbuat. Jadi dalam tulisan ini, penulis memfokuskan pada tahap perkembangan yaitu dari umur 0-12 tahun (masa kanak-kanak sampai masa anak). Sebab menurut penulis masa ini orang tua memegang peran penting dan sangat berpengaruh ke masa kehidupan selanjutnya yakni masa pubertas sampai masa tua. Sebab pada masa itulah dasar kehidupan seseorang terbentuk, serta pengalaman dan pengajaran yang diperolehnya turut membentuk kepribadiannya.

${ }^{7}$ Ibid..,75

${ }^{8}$ Agoes Soejanto, Psikologi Perkembangan (Jakarta: Rieneka Cipta, cet. ke18, 2005),1.

${ }^{9}$ Andi Mappiare, Psikologi Remaja (Surabaya: Usaha Nasional, 1982), 24-25. 
Menurut Stephen Tong, masa kanak-kanak adalah masa yang penting, sebab masa ini memberikan kesan yang sangat mendalam atas setiap kehidupan manusia. Masa yang tidak mungkin terulang yakni paling dasar dan awal serta memberikan kesan yang mendalam dalam hidup seseorang dan tidak akan pernah terlupakan. ${ }^{10}$ Maka masa kanak-kanak ditandai dengan pertumbuhan dan perkembangan yang sangat gemilang khusunya pada daya ingat. Ciri khas pada masa ini pada umumnya nampak jelas dalam kemampuannya atas Tindakan-tindakan yang meniru tentang apa yang diamatinya dan dengan cepat menangkap informasi-informasi yang diperolehnya. Lebih menarik lagi ilah semuanya terekam pada memori dalam ingatannya sehingga tidak mudah dilupakan seumur hidupnya dan tentunya akan memengaruhi pembentukan psikologisnya. Dengan kata lain masa ini adalah masa paling produktif dan maksimal.

Orang tua/Kristen percaya bahwa pembentukan yang berkenan kepada Tuhan tidak terjadi begitu saja tanpa campur tangan Tuhan lewat Firman dan orang-orang yang dipakai-Nya sebagai alat di tangan-Nya. Orang tua merupakan patner Allah di dunia ini yang paling bertanggung jawab dalam mendidik anak-anaknya seturut dengan kehendak Allah tentunya dengan menerapkan kaidah-kaidah/ prinsip-prinsi dasar pendidikan yang Alkitabiah. Maka sebagai orang tua harus menyadari bahwa kedudukan dan fungsinya adalah sebagai figur yang paling dikagumi oleh anakanaknya. Pertumbuhan dan perkembangan anak sangat dipengaruhi oleh orang tua yang mendidiknya lewat keteladan dan pengajaran serta gaya hidup. Pengalaman masa anak-anak menjadi modal dasar dalam memasuki fase selanjutnya.

\section{Dasar Alkitabiah Pendidikan Kristen dalam Keluarga}

Alkitab menjadi dasar bagi tiap kehidupan keluarga Kristen, Alkitab mengajarkan bahwa mendidik anak merupakan kewajiban dan tanggung jawab orang tua sebab ini merupakan perintah Allah. Di bawah ini ada beberapa contoh dari ayatayat dalam Alkitab sehubungan dengan Pendidikan Kristen dalam keluarga:

\section{Ulangan 6:6-10}

Apa yang kuperintahkan kepadamu pada hari ini haruslah engkau perhatikan, haruslah engkau mengajarkannya berulang-ulang kepada anak-anakmu dan membicarakannya apabila engkau duduk di rumahmu, apabila engkau sedang dalam perjalanan, apabila engkau berbaring dan apabila engkau bangun. Haruslah juga engkau mengikatkannya sebagai tanda pada tanganmu dan haruslah itu menjadi lambang di dahimu, dan haruslah engkau menuliskannya pada tiang pintu rumahmu dan pada pintu gerbangmu.

\section{Mazmur 78:5-7}

Telah ditetapkan-Nya peringatan di Yakub dan hukumTaurat diberi-Nya di Israel; nenek moyang kita diperintahkan-Nya untuk memperkenalkannya kepada anak-anak mereka, supaya dikenal oleh Angkatan yang kemudian, supaya anakanak, yang akan lahir kelak, bangun dan menceritakannya kepada anak-anak

10 Stephen Tong, Aristek Jiwa, cet. ke -3 (Jakarta: Lembaga Reformed Injili Indonesia, 2001), 2. 
mereka, supaya mereka menaruh kepercayaan kepada Allah dan tidak melupakan perbuatan-perbuatan Allah, tetapi memegang perintah-perintahnya;

Amsal 22:6: "Didiklah orang muda menurut jalan yang patut baginya, maka pada masa tuanya pun ia tidak akan menyimpang dari pada jalan itu."

Efesus 6:1-6: "Hai anak-anak, taatilah orang tuamu di dalam Tuhan, karena haruslah demikian. Hormatilah ayah dan ibumu inilah suatu perintah yang penting, seperti yang nyata dari janji ini: supaya kamu berbahagia dan panjang umurmu di bumi. Dan kamu bapa-bapa, jangan bangkitkan amarah di dalam hati anak-anakmu, tetapi didiklah mereka di dalam ajaran dan nasehat Tuhan. hai hamba-hamba, taatilah tuanmu yang di dunia dengan takut dan gentar, dan dengan tulus hati, sama seperti kamu taat kepada Kristus. Hai hamba-hamba, taatilah tuanmu yang di dunia dengan takut dan gentar, dan dengan tulus hati, sama seperti kamu taat kepada Kristus, jangan hanaya di hadapan mereka saja untuk menyenangkan hati orang, tetapi sebagai hamba-hamba Kristus yang dengan segenap hati melakukan kehendak Allah."

Ayat-ayat Alkitab terkait pendidikan di keluarga mengajarkan orang tua untuk mendidik serta menuntun anak kepada Kristus yang satu-satunya Juru-selamat, serta diikrarkan orang tua di hadapan Tuhan dan jemaat ketika anak mere-ka diserahkan kepada Kristus. Sangat jelas bahwa, orang tua Kristen bertanggung jawab sepenuhnya mendidik dan mengajaranak-anaknya seturut dengan Firman Allah agar anak-anak mereka mengenal dan menaruh kepercayaannya hanya kepada Allah yang besar, yang telah dan terus menyatakan perbuatan-perbuatan-Nya yang ajaib dalam kehidupan umat manusia khususnya bagi umat yang dikasihi-Nya. Inilah tujuan pengajaran Kristen yang ditetapkan kepada Allah bagi setiap orang tua.

Dalam bukunya, Daniel Nuhamara menjelaskan bahwa baik kewajiban maupun hak orang tua untuk mendidik anak-anak dapat dilihat secara logis dari kepercayaan bahwa anak-anak adalah karunia dari Tuhan melalui orang tua dan di tangan orang tualah tugas pendidikan itu diberikan. Karena itu, orang tua, mempunyai keutamaan (primacy) dalam hak dan kewajiban untuk mendidik anak-anak mereka di dalam takut akanTuhan. ${ }^{11}$ selanjutnya Louis dan Cornelius sependapat bahwa; rumah merupakan pusat system pendidikan bukannya sekolah. ${ }^{12}$ Ellys melanjutkan dalam tulisannya; nilai-nilai yang diajarkan dalam pendidikan kepada anak dari dalam rumah. Hal-hal ini yang diajarkan dari rumah, baik hal-hal positif maupun hal-hal negative dapat lebih berpengaruh pada anak-anak disbanding dengan jika diajarkan di sekolah atau Lembaga lain. ${ }^{13}$ Seterusnya Stephen Tong mengungkapkan bahwa; prinsip penting jikalau kita menjadi orang tua yang tidak menyadari prinsip

11 Daniel Nuhamara, Pembimbing Pendidikan Agama Kristen (Bandung: Jurnal Info Medan), 5960.

12 Louis Berkhof dan Cornelius van Til, Dasar Pendidikan Kristen, Peny. Steve Hendra, Pen. Tim Penerjemah (Surabaya: Momentum 2004), 43.

13 J. Ellys, Kiat Mengasah Kecerdasan Emosional Anak (Bandung: Pustaka), 93. 
ini, maka kita telah gagal menjadi orang tua. Mendidik anak-anak merupakan sesuatu hal yang sangat serius. ${ }^{14}$

Oleh karenanya, orang tua sebagai wakil Allah di dunia ini seharusnya dan selayknya bertanggung jawab penuh atas pendidikan anak-anaknya. Dalam kedudukannya sebagai wakil Allah maka pengajaran yang harus disampaikan kepada anakanak haruslah berfokus pada Allah. Orang tua mengingat posisinya didalam Tuhan dan anak-anaknya, sehingga melalui itu orang tua sadarakan perannya. Hendaklah keadilan serta kebenaran dan kasih-Nya mewarnai sikap dan tindakan orang tua terhadap anak-anaknya. Dengan bijaksana orang tua harus tahu kapan saat-saat berbicara, kapan diam serta bagaimana mengatakan agar anak dapat mengerti dengan baik dan mau melakukan dengan kerelaan, serta kapan orang tua harus menerapkan hukuman serta keputusan-keputusan yang penting sangat menentukan. Orang tua memerlukan kebijaksanaan agar dapat menyeimbangi antara kasih, keadilan dan tindakan, sebab orang tua memerlukan kekuatan, kesabaran dan kasih dalam mendidik dan membesarkan anak-anak mereka. Menjadi orang tua yang bijaksana perlu campur tanganTuhan didalamnya.

\section{Orang tua merupakan Teladan bagi Anak-anaknya}

Keteladaan hidup merupakan cerminan dari diri sendiri. Kepemimpinan Kristen adalah suatu proses terencana yang dinamis dalam konteks pelayanan pendidikan Kristen ( menyangkut waktu, tempat dan situasi khusus), yang di dalamnya ada campur tangan Allah, Ia memanggil bagi diri-Nya guna mencapai tujuan Allah yakni pendidikan Kristen. ${ }^{15}$ Kualifikasi yang harus diperhatikan oleh seorang pemimpin ialah masalah spiritualitas, kemampuan intelekual, kestabilan emosi, kesanggupan bersosialisasi serta kejujuran moral. ${ }^{16}$

Keteladanan hidup dapat dilihat meliputi; apa yang kita katakan, apa yang kita lakukan, konsekuensi, hukuman, dan pujian semuanya kaya akan pengajaran yang benar. Kita mengajarkan lewat teladan hidup dan pribadi kita sendiri yang nyata dihadapan anak-anak kita maka ini merupakan sebuah metode pengajaran yang paling efektif. ${ }^{17}$ Sebab dengan mendidik anak itu sangat berguna sebab tujuannya mulia namun berat. Dengan demikian orang tua harus menjadi pelaku utama sebagai pengajar atas anak-anaknya yang keluar dari mulutnya. Jika tidak, maka pengajarannya tidak akan berhasil, mengajar artinya memberi teladan. ${ }^{18}$ Anak-anak selama hidupnya memerlukan teladan yang baik terhadap orang tuanya. ${ }^{19}$ Sebab

\footnotetext{
14 Stephen Tong, Membesarkan Anak Dalam Tuhan (Jakarta: Lembaga Reformed Injili Indonesia), 5.

15 Yakub Tomatala,Kepemimpinan Kristen ( Jakarta: YT Leadership Foundational, 2002), 12.

16 Yosafat B, Integritas Pemimpin Pastoral ( Yogyakarta: Andi, 2010), 15.

17 L. Stanton, Jones, Brenna B, “Bagaimana dan Kapan Memberitahu Anak Anda Mengenai Seks. Pen.Fenny Veronica dan Ina Elia” (Surabaya: Momentum, 2004), 67-68.

18 Bailey Becky A, Tujuan Keterampilan Dasar Untuk Mengubah Konfluk Menjadi Kerja Sama

Peny. Fransiska Susanti.Pen.T Seputro ( Jakarta: Gramedia Pustaka Utama, 2004)

${ }^{19}$ Severe Sal, Bagaimana Bersikap Pada Anak Agar Anak Bersikap Baik.

Peny.Malikas.pen.T.Hermaya.cet. ke-5 “( Jakarta: PT Gramedia Pustaka Utama, 2005), 5.
} 
tanpa keteladanan ajaran kita akan kehilangan otoritasnya sehingga kita dicemooh oleh anak dan dianggap munafik. ${ }^{20}$

Jadi keteladan hidup merupakan cara yang paling efektif dalam mendidik anak-anak serta bermanfaat bagi perkembangan kepribadiannya. Orang tua harus dapat menjadi teladan bagi seisi rumahnya, sehingga mampu mengarahkan anakanaknya kepada kebenaran Allah. Orang tua pelaku utama dalam membina dan mendidik, menyatakan kasih dan kebenaran melalui tindakan yang nyata dalam kehidupan sehari-hari. Prinsip inilah yang harus dipahami oleh setiap orang tua Kristen sehingga pola mendidik anak yang diterapkan dalam keluarga selaras dengan tujuan, rencana dan maksud Allah. Orang tua yang memperlakukan anakanaknya sebagai pribadi yang berharga sekalipun memiliki kekurangan dan kelebihan dalam diri mereka adalah orang tua yang memahami Firman Allah dengan baik. Mendidik dan membesarkan anak dengan penuh kasih adalah anugerah Tuhan yang dititipkan kepada orang tua. Mereka menyadari bahwa tiap anak adalah kepunyaan Allah, yang harus diperlakukan dengan penuh cinta, kasih sayang dan tanggung jawab penuh. Pendidikan tanpa kasih akan menghasilkan kekerasan atau kekejaman pada anak-anak.

\section{Pendidikan Kristen di Era Digital}

Menurut Sidjabat dalam bukunya yang berjudul Menjadi Guru yang Profesional: Pendidikan Kristen merupakan usaha sengaja dan sistematis, ditopang oleh upaya rohani dan manusiawi untuk mentransmisikan pengetahuan, nilai, sikap, keterampilan dan tingkahlaku yang mengupayakan perubahan-perubahan informasi pribadi, kelompok, bahkan struktur oleh kuasa Roh Kudus sehingga peserta didik hidup sesuai dengan kehendak Allah sebagaimana dinyatakan Alkitab, terutama dalam Yesus Kristus. ${ }^{21}$ Pendidikan Kristen sepenuhnya berpusat pada iman Kristen, Alkitab menjadi standart dalam pengajarannya tanpa mengabaikan ilmu pengetahuan yang lain. Dengan kata lain seorang pendidik Kristen menjalankan tugasnya secara professional dalam bekerja. Profesionalisme berbicara tentang mutu dan kualitas dari pendidik itu sendiri, baik dalam berkata-kata maupun dalam Tindakan nyata sehari-hari.

Era Digital ditandai dengan masuknya teknologi informasi dan komunikasi yang terus berkembang sehingga mempengaruhi kehidupan bermasyarakat. Tujuannya ialah untuk memudahkan akses informasi bagi perkembangan masyarakat, bangsa maupun negara. Sebab melaluinya sebagai penunjang komunikasi yang efektif dalam proses pembelajaran. Aditiawarman merangkum ada 7 fungsi Era Digital dalam dunia pendidikan yang di antaranya adalah: Sumberilmu; Media pem-

20 Jarot Wijanarko,Mendidik Anak Untuk Meningkatkan Kecerdasan Emosional dan Spiritual (Jakarta: Gramedia Pustaka Utama, 2005), 39.

21 Sidjabat. S, Menjadi Guru Profesional (Bandung: Kalam Hidup, 2011), 28 
belajaran, Penunjang fasilitas pendidikan, Alat ukur standart kompetensi, Pelengkap/penunjang administrasi, Manajemen sekolah, Infrastruktur pendidikan. ${ }^{22}$

Dengan adanya Era Digital telah memberi banyak perubahan dalam masyarakat secara khusus bidang pendidikan. Guru dituntut untuk lebih professional lagi. Masa pandemic mengajarkan kita bagaimana kita bisa dan mampu memakai teknologi yang canggih. Sekalipun guru tidak bisa bertatapan muka dengan murid yang diajar. Tentunya dari sisi yang lain akan ada sisi negative.

Maka ada 4 alasan mengapa mengajarkan konsep-konsep Kristen pada anak kecil. Pertama, Alkitab mengajarkan agar anak-anak diajarkan di dalam iman Kristen; kedua; mustahil memisahkan anak dari agama; ketiga, kemampuan guna mengatasi konsep-konsep yang sulit diperoleh lewat pengalaman pribadi; keempat. Alkitab mengajarkan bahwa iman Kristen mampu memenuhi kebutuhan-kebutuhan anak. ${ }^{23}$ Selanjutnya Dien Sumiyati ningsih dkk menyatakan bahwa; teknologi memudahkan semua aktivitas manusia untuk melaksanakan kegiatan yang ada. Misalnya dalam aspek ekonomi sudah lebih mempermudah penjualan lewat internet sehingga jangkauannya lebih luas bukan lagi dengan system barter yakni mencari tempat untuk melakukan jualan sehingga lebih mudah memasarkannya. ${ }^{24}$

Teknologi selalu disangkut pautkan dengan alat-alat canggih dan modern yang mempermudah kehidupan, sedangkan ilmu pengetahuan disangkut pautkan dengan teori-teori tentang hal-hal yang berkaitan dengan kehidupaan manusia. Tetapi kemajuan teknologi tidak selalu memberikan dampak yang baik. Dengan kemajuan industry teknologi kecenderungan manusia bergantung kepada IPTEK dan mulai mengeserposisi utamaTuhan Allah dalam kehidupan manusia. Dalam konteks ini, teknologi adalah keadaan pengetahuan manusia tentang bagaimana cara untuk memadukan sumber-sumber, guna menghasilkan produk-produk yang dikehendaki, menyelesaikan masalah, memenuhi kebutuhan atau memuaskan keinginan yang meliputi cara atau metode, keterampilan atau proses, Teknik perangkat dan bahan mentah. Teknologi diciptakan oleh manusia pada mulanya hanya sebuah alat-alat sederhana, namun memberikan dampak yang sangat besar bagi manusia, dengan motivasi berkelanjutan yang dilakukan oleh manusia, membuat teknologi sangat cepat berlangsung. ${ }^{25}$

Pendidikan Kristen di Era Digital mengajarkan kita untuk terus maju dan memiliki pemikiran yang luas. Pendidikan Kristen di Era Digital menolong kita untuk terus berkontribusi dalam dunia pendidikan. Sebagai orang Kristen Era Digital tidak membuat kita menjauhkan diri dari Allah, melainkan membantu kita untuk terus berkarya dan terus beriman pada Tuhan. Dengan munculnya era digital dalam dunia pendidikan bukan menjadikan guru atau murid tidak makin profesioanl baik dalam

\footnotetext{
22 Mac Aditiawarman, Variasi Bahasa Masyarakat (Padang: MahasiswaFakultas Sastra UniveristasEkasakti dan Dosen, ed: 2019), 146

${ }^{23}$ Wes Haystead, Menggenalkan Allah Kepada Anak (Yogyakarta: Yayasan Gloria, 1998), 15.

${ }^{24}$ Sumiyatiningsih, Stefanus dan Robert P. Borrong, Pendidikan Agama Kristen dan Budi Pekerti Kelas IX (Jakarta: Kementerian Pendidikan dan Kebudayaan, 2014), 112-115.

${ }^{25}$ KalvoderTogatorop, Eksequendum Didaktik: Pendidikan Agama Kristen di Sekolah,Jemaat dan Masyarakat Plural (Banten: YPSIM, 2020), 163-164
} 
proses pembelajaran. Era digital membuat seseorang menyadari bahwa ilmu pengetahuan itu terbuka dan mudah diakses, tidak harus masuk kelas secara formal. Proses pembelajaran dapat terjadi kapan dan dimana saja, sehingga terciptanya produk-produk unggulan. Teknologi yang makin berkembang akan menyadarkan seseorang bahwa dunia sempit. Oleh sebab itu mengajarkan firman Allah kepada anakanak sejak dini akan membuat mereka makin mencintai dan berkompetensi dalam bidang pendidikan. Firman Allah adalah tolah ukur dalam perkembangan era digital agar tidak menyimpang dari ajaran-ajaran Alkitab.

\section{KESIMPULAN}

Pendidikan Kristen adalah pendidikan yang bersumber pada Alkitab, yang mengajarkan bukan hanya pengetahuan melainkan iman dan karakter yang selaras dengan Kristus. Pendidikan itu dimulai di tengah-tengah keluarga dan orang tua adalah guru yang terbaik bagi anak-anaknya. Peranan orang tua sangat menentukan keberlangsungan anak-anaknya. Orang tua menjadi patner Allah, keteladanan orang tua akan menjadikan anak melihat dan mengaguminya sebagai orang yang terdekat dengan mereka. Pendidikan di Era Digital diharapkan memberikan kontibusi bagi kemajuan pendidikan di Indonesia secara khusus. Dangkalnya pemahaman orang tua tentang pentingnya menjadi teladan serta perlunya menyeimbangkan antara kasih dan keadilan dalam menjalankan disiplin menimbulkan sikap yang terlalu keras dalam mendidik anak-anak, maupun terlalu memperbolehkan anak-anak melakukan apa saja yang diinginkannya. Kedua sikap ini merugikan perkembangan anakanak. Dan keduanya merupakan kekerasan yang mempengaruhi psikis anak-anak.

\section{REFERENSI}

Berkhof Louis dan Van Til Cornelius. Dasar Pendidikan Kristen, Peny. Steve Hendra, Pen. Tim Penerjemah". Surabaya: Momentum, 2004.

B. Yosafat. Integritas Pemimpin Pastoral, Yogyakarta: Andi, 2010.

Becky Bailey A. Tujuan Keterampilan Dasar Untuk Mengubah Konfluk Menjadi Kerja

Sama, Peny. Fransiska Susanti.Pen.T Seputro. Jakarta: Gramedia Pustaka Utama, 2004.

Ellys J. Kiat Mengasah Kecerdasan Emosional Anak, Bandung: Pustaka.

Kholifah Siti \& Suyadnya Wayan I. Metodologi Penelitian Kualitatif Berbagai

Pengalaman Dari Lapangan, Depok: PT Raja Grafindo Persada, 2018.

Gray John. Children Are From Heaven: Cara Membesarkan Anak Secara Positif Agar Anak Menjadi Kooperatif Percaya Diri Dan Memahami Perasaan Orang lain, Jakarta: PT Gramedia Pustaka, 2004.

Moleong Lexy J. Metodologi Penelitian Kualitatif Edisi Revisi, Bandung: PT Remaja Rosdakarya, 2010.

Mappiare Andi. Psikologi Remaja, Surabaya: Usaha Nasional, 1982.

Nuhamara Daniel. Pembimbing Pendidikan Agama Kristen, Bandung: Jurnal Info Medan

Noor Juliansyah. Metodologi Penelitian, Jakarta: Kencana Prenada Media Group, 2011.

Soejanto Agoes. Psikologi Perkembangan, Jakarta: Rieneka Cipta, cet.ke18, 2005. 
Stanton L Jones, B Brenna. Bagaimana dan Kapan Memberitahu Anak Anda Mengenai Seks, Pen.Fenny Veronica dan Ina Elia". Surabaya: Momentum, 2004.

Sal Severe. Bagaimana Bersikap Pada Anak Agar Anak Bersikap Baik,

Peny.Malikas.pen.T.Hermaya.cet. ke-5 “. Jakarta: PT Gramedia Pustaka Utama, 2005.

Tong Stephen. Arsitek Jiwa 1, Jakarta: Lembaga Reformed Injili Indonesia, 2009

Tong Stephen. Aristek Jiwa, cet. ke -3, Jakarta: Lembaga Reformed Injili Indonesia, 2001.

Tong Stephen, Membesarkan Anak Dalam Tuhan, Jakarta: Lembaga Reformed Injili Indonesia.

Tomatala Yakub. Kepemimpinan Kristen, Jakarta: YT Leadership Foundational, 2002.

Wahyuni Sri, Psikologi Remaja: Penanggulangan Kenakalan Remaja. Luwuk Banggai: Pustaka Star's Lub, 2021.

Wijanarko Jarot, Mendidik Anak Untuk Meningkatkan Kecerdasan Emosional dan Spiritual. Jakarta: Gramedia Pustaka Utama, 2005. 